\title{
Survival and establishment in field of mangaba seedlings transplanted at different ages
}

\author{
Marcos Paulo dos Santos*, Ana Paula Silva Siqueira², Lismaíra Gonçalves Caixeta Garcia', \\ Luís Henrique Costa Vasconcelos', Eli Regina Barboza de Souza'
}

\author{
'Federal University of Goiás, Goiânia, Brazil \\ ${ }^{2}$ Federal Institute of Science and Technology, Morrinhos, Brazil \\ *Corresponding author, e-mail: marcospaulo_agronomo@hotmail.com
}

\begin{abstract}
The propagation of mangaba (Hancornia speciosa Gomes) occurs mainly by seeds, a lower cost method that guarantees genotypic diversity. The great barrier is the lack of knowledge of the proper transplanting time of these seedlings. This way, the objective of this study was to evaluate the development of mangaba seedlings transplanted at different ages during the summer in Goiânia, Brazil. A randomized complete block design was used in a $2 \times 4$ factorial arrangement, with two mangaba subspecies (gardneri and cuiabenses) and four transplanting ages $[45,60,75$ and 90 days after sowing (DAS)], with four replications. Before transplanting, a destructive analysis was carried out on three plants of each subspecies to determine the biometric characteristics as a function of seedling age. The field evaluations initiated at 120 DAS, evaluating monthly the seedling survival (\%), plant height, stem diameter and number of live leaves per plant until 210 DAS. The biometric characteristics were not affected by the mangaba subspecies. The plant survival decreased linearly throughout the experimental period, regardless of the subspecies. The interaction age transplanting $x$ DAS showed that at 210 DAS the seedlings transplanted later presented greater growth in height and number of live leaves. Regardless of the subspecies, the mangaba presents limitations for establishment in the field, and it is recommended the transplantio of seedlings with 90 days of age.
\end{abstract}

Keywords: Cerrado, cuiabenses, gardneri, native fruit

\section{Introduction}

In recent years, the main economic base of the Brazilian Midwest region has been extensive livestock farming and agriculture, so immense areas with native species have been replaced by pasture and agricultural monocultures. As a consequence of the anthropization, there were transformations in the soil profile, as well as reduction of the fauna and flora biodiversity, with reflexes throughout the ecosystem (Cunha et al., 2008). However, the Cerrado flora has numerous fruit species with potential for agricultural use. According to Melchior et al. (2006) before the fragmentation of the original cerrado, studies about propagation and rational exploitation of native fruit species are necessary, especially those with interesting organoleptic characteristics and economic potential.

There are few scientific researches on botanical surveys and tests for propagation and seedling production of Cerrado fruit plants, especially for mangaba (Harconia speciosa Gomes), endemic to Cerrado. Studies with this species are still recent, considering that it is a fruit crop still under domestication. Themes such as the seed physiological quality evaluation, selection of genotypes, development and adaptation of agronomical practices and aspects related to pre and post-harvest of the fruit need to be further investigated. 
The propagation of Cerrado species is usually performed by seeds, which is a lower cost method and guarantees genotypic diversity and, therefore, this method is also used for these species to recover degraded areas (Junqueira et al., 2008). Observing this propagation type, an important factor, which can affect the quality and fruit yield of plants, is the high age at the transplantation. This can impair the development of plant roots and shoots. If the seedling is maintained for a very long period waiting to be transplanted, it may present nutrient deficiency, and even root folding may occur (Salata et al., 2011). The time at which the seedlings remain with their restricted root system should be the least possible, because when transplanted to the field, they are often unable to compensate for evapotranspiration, even if well irrigated (Pereira \& Martinez, 1999). However, if the seedlings are too young transplanted to the field, they may have an underdeveloped root system, can not withstand wind, heavy rains, and pest and disease attack. The definition of the optimal timing for seedling transplanting has been a research subject for commercial vegetables crops (Salata et al., 2011; Magro et al., 2011) and also fruit trees (Bregonci et al., 2008) due to their capacity to improve plant development in the field.

According to the information above described, this research work aimed to evaluate the survival and initial development of mangaba seedlings of two subspecies, propagated by seeds, and transplanted to the field at different ages.

\section{Material and Methods}

Mangaba mature fruits, newly fallen on the ground, were collected from plants with nearly 15 years old, of two subspecies, Hancornia speciosa Gomes var. Gardneri and Hancornia speciosa Gomes var. Cuiabenses, belonging to the germplasm of Cerrado native plants of the Federal University of Goiás, Goiânia, Brazil, installed in the geographical coordinates, latitude $16^{\circ} 35^{\prime} 12$ "S, longitude $49^{\circ} 21^{\prime} 14^{\prime \prime} \mathrm{W}$ and $730 \mathrm{~m}$ altitude. The soil in the experimental area is classified as Dark Red Oxisol. The climate in the region is Aw, presenting rainy summer and dry winter, with annual precipitation of $1800 \mathrm{~mm}$ and average temperature of $23^{\circ} \mathrm{C}$. The dry season predominates from May to October (Alvares et al., 2014).

After collection, the fruits were washed in running water and stored for six days at approximately $8^{\circ} \mathrm{C}$. The fruits were then handstripped and washed in running water until the pulp was completely removed, and the seeds were laid out on paper towel for natural drying. Subsequent to drying, sowing was performed. Seeds were sowed at $2 \mathrm{~cm}$ depth in polyethylene bags (2 kg capacity), filled with the mixture: commercial substrate (Basaplant ${ }^{\circledR}$ ) + charcoal rice husk + ground soil, in a proportion of 1:1:3 according to recommendation of Silva et al. (2009) to obtain high seedling emergency speed index (SESI) and seed germination of mangaba. The containers containing substrate and mangaba seeds were kept in a nursery with $100 \%$ luminosity and wetted until reaching saturation every two days during the seedling production.

The experimental design was a randomized complete block, in a $4 \times 2$ factorial arrangement, four transplanting ages $(45,60$, 75 and 90 DAS) and two mangaba subspecies (Gardneri and Cuiabenses), with four replications and six plants in each experimental unit. Before transplanting, destructive analysis was carried out on samples of three plants of each subspecies to determine the biometric characteristics due to the seedling age. In these samples the height and number of leaves were initially determined. Afterwards the fractions were separated: shoots and roots, which were weighed when still fresh and immediately after oven dried at $75^{\circ} \mathrm{C}$ for $48 \mathrm{~h}$ to obtain the dry mass of the respective fractions.

The transplantation of Gardneri and Cuiabenses seedlings for field conditions occurred in October-November 2015 (summer). These seedlings were transplanted to $0.2 \mathrm{~m}$ wide $\times 0.2$ $\mathrm{m}$ long $\times 0.2 \mathrm{~m}$ deep caves. After transplanting, the seedlings were wetted during five days, from which they received water via rainfall during the rainy season.

The biometric and survival data of the plants in field were analyzed as time-repeated measures (120, 150, 180 and 210 DAS), admitting the time factor in the subplot, using analysis of 
variance according to the model below, followed by comparison of averages and regression for significant variation sources $(p<0.05)$. The statistical model was: Yijkz $=\omega z+\mu+a i+\beta j+$ $(a \beta) i j+(P / T) i j+D k+\left(\omega^{*} D\right) z k+\left(a^{*} D\right) i k+\left(\beta^{*} D\right) j k+$ $\left(a^{*} \beta^{*} D\right) i j k+\varepsilon i j k z$, where: $Y i j k z=$ biometric response of the $z$-th repetition at age $i$ of subspecies $j$ at time $k ; \omega=$ is the effect of the z-block on observation; Yijkz $\mu$ = constant; ai = age effect, where $\mathrm{i}=45,60,75$ and $90 \mathrm{DAS} ; \beta \mathrm{j}=$ effect of the mangaba subspecies j, being $\mathrm{j}==$ Gardneri and Cuiabenses; $(a \beta) i j=$ is the effect of the interaction of the ith factor a level with the ith factor level $\beta$; $(P / a \beta) i j=$ effect of the z-th repetition, within the age $i$, of the subspecies $j$ and of the interaction $i * j$ (residue a); Dk = effect of the day after sowing $k$, so that $k=120,150,180$ and $210 ;\left(\omega^{*} D\right) z k=$ effect of interaction block $\times$ DAS; $\left(\beta^{*} D\right) j k=$ effect of the interaction mangaba subspecies $\times$ DAS; $\left(a^{*} \beta^{*} D\right)$ ijk $=$ effect of the interaction transplanting age $\times$ mangaba subspecies $\times$ DAS; cijkz = random error related to observation Yijkz (residue b). In the model employed all factors were considered as being of fixed effects.

The plant development in the field was evaluated by measuring height $(\mathrm{cm})$, stem diameter (mm), number of live leaves and plant survival (\%), at 30 days intervals from 120 to 210 DAS. The plant height was determined with a $100 \mathrm{~cm}$ millimeter ruler, obtaining the seedling measurements from the ground until the plant apex (insertion of the last leaves); the stem diameter determined by digital paquimeter and the number of leaves by counting from the cotyledon leaves.

Statistical analyzes and regression adjustments of the biometric and survival data of the plants in field to determine the optimal time of transplanting mangaba seedlings were carried out using the statistical program $\mathrm{R}$ version 3.3.

\section{Results and Discussion}

The biometric characteristics of mangaba plants at the time of transplanting did not differ among the subspecies, being observed effect only for the seedling age (Figure 1). The variables plant height, leaf number and fresh shoot mass (FSM) presented linear data distribution, with higher values assigned to older seedlings (Figures 1a, 1b, 1c), respectively. This behavior is explained by the plant ontogeny. As a result of the phenological stages, changes in the form, physiology, chemical composition and resistance to pathogens and stresses occur, which reflects on mass accumulation (Kudo et al., 2008; Khan et al., 2010). In addition, the growth rates are attenuated with plant development, when the first formed leaves expand completely, making the photosynthetic balance positive. This results in greater carbohydrate targeting and accumulation for plant growth points, apical and root meristems.

On the other hand, the variables root fresh mass (RFM) and dry mass of shoots and roots (SDM and RDM) presented a quadratic response as a function of the transplanting age (Figures 1d, 1e, 1f). The maximum RFM was observed in 67 days age seedlings, and the SDM and RDM minimum of seedlings aged 65 and 71 days, respectively. The fact that the maximum RFM occurred in the same period of the lowest plant dry mass can be explained by the root and shoot composition. At the plant development beginning, the water amount in the tissues is greater than that of carbohydrates due to the low production of organic compounds. However, as the plant develops the assimilated water/ carbohydrate ratio, especially in stem and/or shoots decreases due to aging, cell lignification, lower water content in these organs and storage of structural matter (Eustáquio Filho et al., 2006). As a consequence of this, there is a dry mass content increase, as observed from the 70 days (Figures le and 1f). In plants the accumulation of dry biomass is exponential and occurs until the physiological maturity phase, from which biomass losses begin to occur due to organ senescence.

The dry mass decrease of both roots and shoots during the aforementioned period may still have been caused by a physical limitation promoted by the container, causing a growth stoppage. Antoniazzi et al. (2013) analyzing Cedrela fissilis Vell. (Cedar) seedlings found that root development is directly related to the size and volume of the container used. By the restriction imposed to the roots in relation to the seedling size, it is also considered that the root mass ratio is an important factor for the survival 
and establishment of seedlings in field. In the present study, at 70 days after sowing, there was a resumption of dry biomass accumulation for both roots and shoot. The stress caused by the container may have been overcome with increasing emission of radicels and shoots with the aging of the seedling, increasing the accumulated dry biomass.
The dry biomass is indicative of plant growth, the greater its accumulation, the greater the possibility of new organs formation (meristems and apices). Therefore, it is noteworthy that seedlings at 45 and 90 days old promoted greater biomass accumulation, which consequently may favor the seedling development in the field.

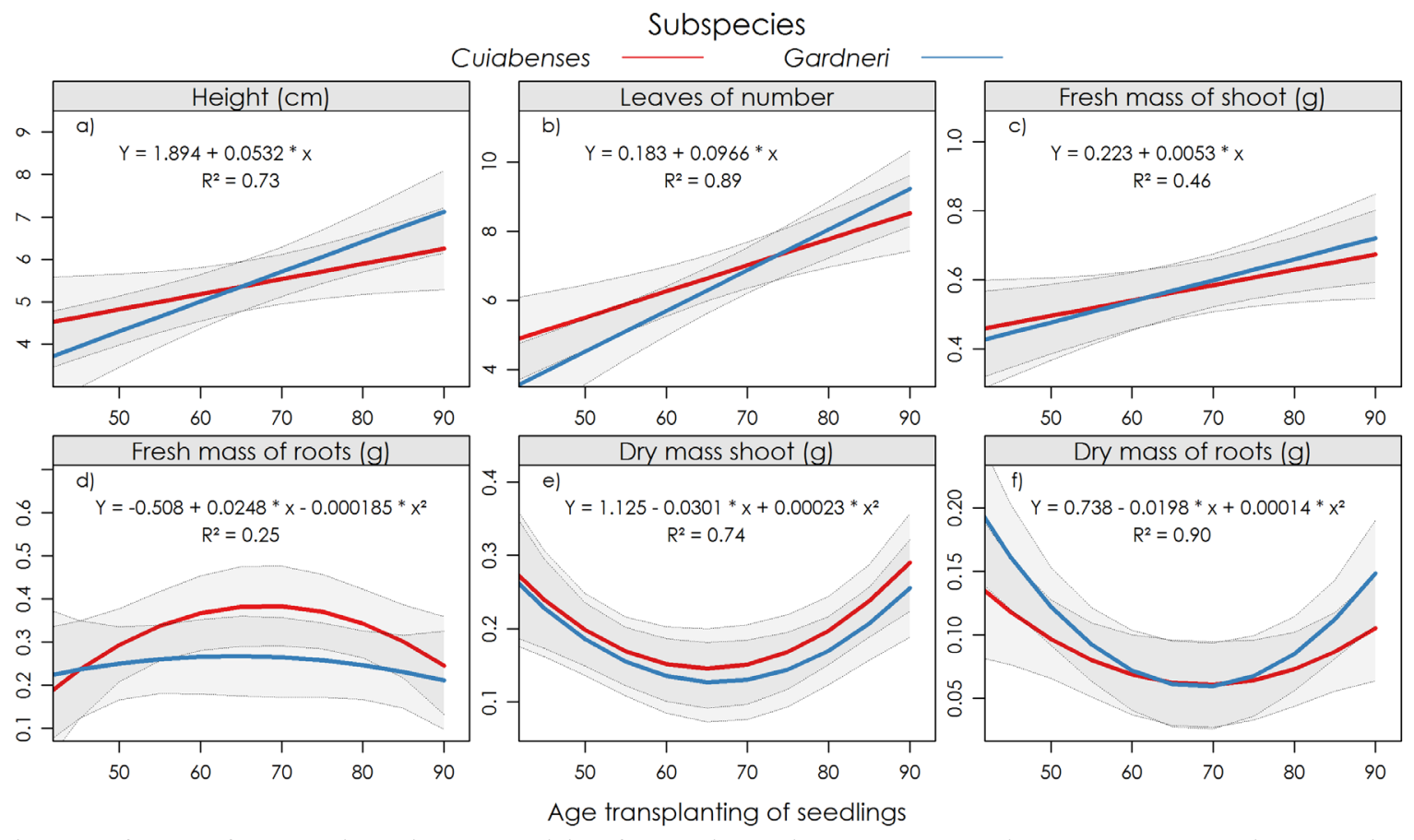

Figure 1. Influence of age on biometric characteristics of Harconia speciosa Gomes var. Cuiabenses and Gardneri. Colored lines and gray bands in the graphs $(a, b, c, d, e, f)$ represent the regression trend lines and the confidence intervals at $5 \%$ probability of error.

In relation to the field evaluations, the plant survival at the end of the experimental period presented an average of $67.4 \%$, independently of the subspecies used, as well as the seedling transplanting age. It was observed that survival reduced linearly with time, which shows mangaba has limitations in field establishment (Figure 2).

The development of established plants in field was affected by the interaction: age of seedlings transplanting $x$ days after sowing (Figure 3). From the 210 days after sowing, seedlings transplanted to the field later (90 days) presented higher height and number of live leaves (Figures $3 a$ and $3 c$ ), which corroborates the better condition presented by these seedlings before transplanting (Figures la, lb, 1c, le, 1f). The positive effect of the higher plants prior to transplanting was also verified in yellow passion fruit, reflecting the formation of more developed plants in the field (Verdial et al., 2000) and higher fruit yields (Zaccheo et al., 2013).

In contrast to plant height and number of leaves, the stem diameter was not increased by transplanting older seedlings (Figure 3b), being observed at 210 days greater stem diameter for transplanted seedlings with an approximate age of 78 days. Seedlings that remain for a long time in container (tube or bag) can root up, steep, and consequently decrease the stem diameter. This latter response occurs in most cases as a function of the reserve mobilization from the cortex to the parenchyma cells as a way of adapting to impediments in respiratory processes, causing stem hypertrophy (Walfhoff et al., 1998)

It was observed during the evaluation period that, from 210 days after sowing, there was a tendency to decrease the height/ stem diameter ratio, when the seedlings were transplanted at 90 days of age: $14.37<4.50$ 
$<5.02>4.82$ at 120,150, 180 and 210 days after sowing, respectively). In addition, it is important to note that the higher the plant resistance, the more resistant the plants are to environmental conditions, as a result of the greater balance between the plant parts (Silva et al., 2007).

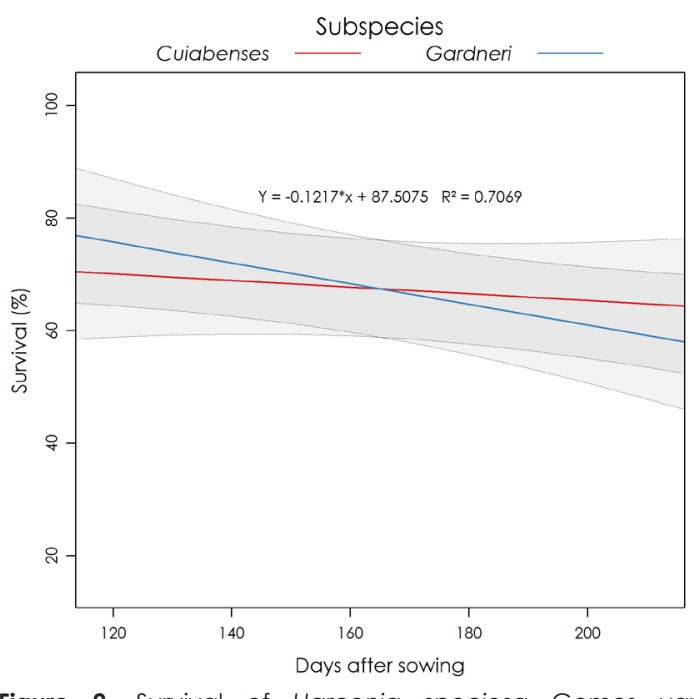

Figure 2. Survival of Harconia speciosa Gomes var. Cuiabenses and Gardneri plants. Colored lines and gray bands in the graph represent trends and confidence intervals at $5 \%$ probability of error for each subspecies.
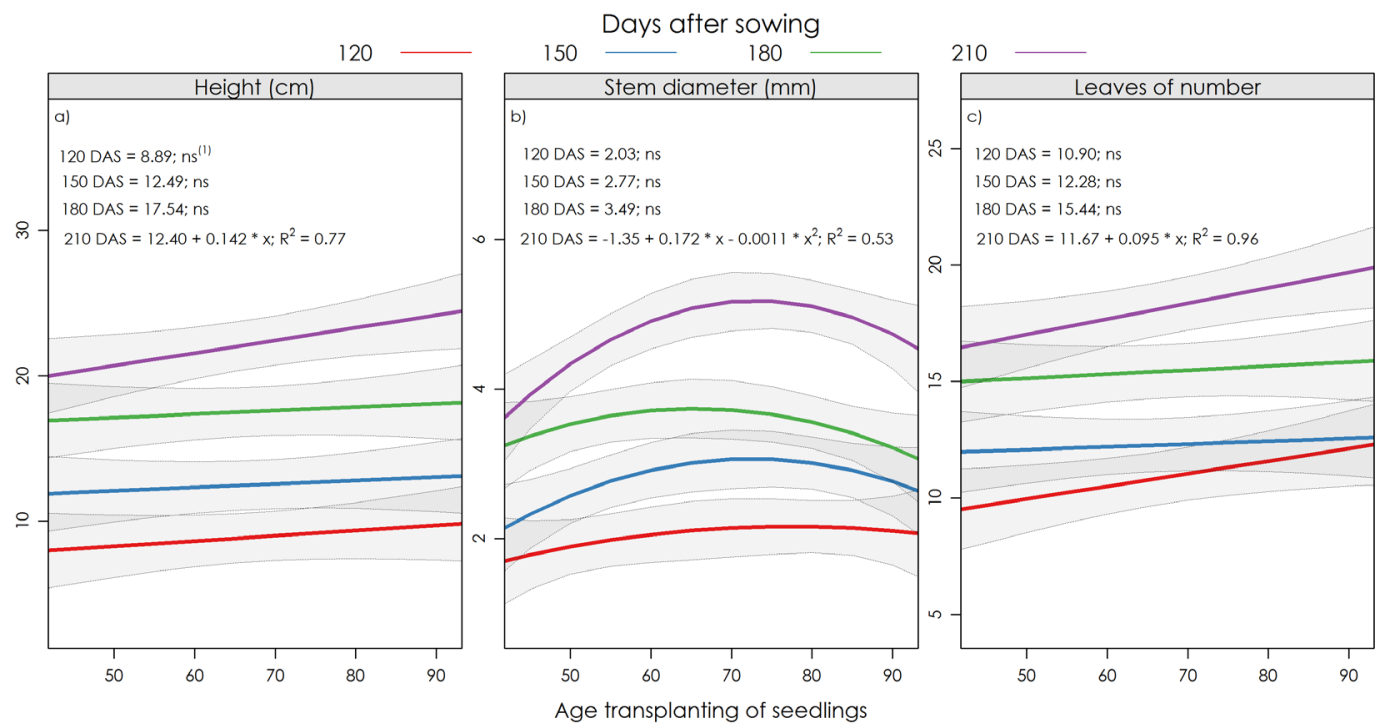

Figure 3. Dynamics of plant growth (a), stem diameter (b) and number of leaves (c) increase in Harconia speciosa Gomes var. Cuiabenses and Gardneri plants transplanted with different ages from 120 to 210 days after sowing. Colored lines and gray bands on the graphs $(a, b, c)$ represent the trend lines of the regressions and the confidence intervals at $5 \%$ probability of error. 1 ns $=P>0.05$.

\section{Conclusions}

1 - The survival of mangaba plants reduces over time, regardless of the seedling age of transplanting.

2 - Hancornia speciosa Gomes seedlings of Gardneri and Cuiabenses cultivars transplanted at 90 days of age develop better under field conditions.

\section{References}

Alvares, C.A., Stape, J.L., Sentelhas, P.C., Gonçalves, J.L.D.M., Sparovek, G. 2014. Köppen's climate classification map for Brazil. Meteorologische Zeitschrift 22: 711-728.

Antoniazzi, A.P., Binotto, B., Neumann, G.M., Sausen, L.T., Budke, J.C. 2013. Eficiência de recipientes no desenvolvimento de mudas de Cedrela fissilis Vell. (Meliaceae ). Revista Brasileira de Biociências 11:313-317. 
Aumonde, T.Z., Lopes, N.F., Peil, R.M.N., Moraes, D.M., Pedó, T. 2011. Análise de crescimento do híbrido de mini melancia Smile enxertada e não enxertada. Revista Brasileira de Agrociência 36: 677-681.

Blum, A. 2009. Effective use of water (EUW) and not water-use efficiency (WUE) is the target of crop yield improvement under drought stress. Field Crops Research 112: 119-123.

Bregonci, I.S., Reis, E.F., Almeida, G.D., Brum, V.J., Zucoloto, M. 2008. Avaliação do cresciemento foliar e radicular de mudas micropropagadas do abacaxizeiro cv. Gold em alcimatação. Idesia 26: 87-96.

Cunha, N.R.S., Lima, J.E., Gomes, M.F.M., Braga, M.J. 2008. A intensidade da exploração agropecuária como indicador da degradação ambiental na região dos Cerrados, Brasil. Revista de Economia e Sociologia Rural 46: 291-323.

Eustáquio Filho, A., Santos, P.E.F., Silva, W.R. 2010. Inter relações entre anatomia vegetal e degradação ruminal de plantas forrageiras. Pubvet 4: 1-24.

Junqueira, N.T.V., Faleiro, F G., Braga, M.F., Peixorto, J.R. 2008. Domesticação de espécies da flora nativa do Cerrado. In: Parron, L.M et al.(Org.). Cerrado: Desafios e oportunidades para o desenvolvimento sustentável. Embrapa Cerrados, Brasil. p. 125-163.

Khan, H.R., Paull, J.G., Siddique, K.H.M., Stoddard, F.L. 2010. Faba bean breeding for droughtaffected environments: A physiological and agronomic perspective. Field Crops Research 115: 279-286.

Kudo, G., Ida, T.Y., Tani, T. 2008. Linkages between phenology, pollination, photosynthesis, and reproduction in deciduous forest understory plants. Ecology 89: 321-331.

Magro, F.O., Salata, A.C., Bertolini, E.V., Cardoso, A.I.I. 2011. Produção de repolho em função da idade das mudas. Revista Agroambiente 5: 119 123.

Melchior, S.J., Custódio, C.C., Marques, T.A., Machado Neto, N.B. 2006. Colheita e armazenamento de sementes de gabiroba (Campomanesia adamantium Camb.

Myrtaceae) e implicações na germinação. Revista Brasileira de Sementes 28: 141-150.

Pereira, P.R.G., Martinez, H.E.P. 1999. Produção de mudas para o cultivo de hortaliças em solo e hidroponia. Informe Agropecuário 20: 24-31.

Salata, A.C., Higuti, A.R.O., Godoy, A.R., Magro, F.O., Cardoso, A.I.I. 2011. Produção de abobrinha em função da idade das mudas. Ciencia e
Agrotecnologia 35: 511-515.

Silva, E.A., Maruyama, W.I., Oliveira, A.C., Bardiviesso, D.M. 2009. Efeito de diferentes substratos na produção de mudas de mangabeira (Hancornia speciosa). Revista Brasileira de Fruticultura 31: 925-929.

Silva, R. R., Freitas, G.A., Siebeneichler, S.C., Mata, J.F., Chagas, J.R. 2007. Desenvolvimento inicial de plântulas de Theobroma grandiflorum (Willd. ex Spreng.) Schum. sob influência de sombreamento. Acta Amazonica 37: 365-370.

Verdial, M.F., Lima, M.S., Tessarioli Neto, J., Dias, C.T.S., Barbano, M.T. 2000. Métodos de formação de mudas de maracujazeiro amarelo. Scientia Agrícola 57: 795-798.

Zaccheo, P.V.C., Aguiar, R.S., Stenzel, N.M.C., Nevez, C.S.V.J. 2013. Tamanho de recipientes e tempo de formação de mudas no desenvolvimento e produção de maracujazeiroamarelo. Revista Brasileira de Fruticultura 35: 603-607.

Waldhoff, D., Junk, W.J., Furch, B. 1998. Responses of three central Amazonian tree species to drought and flooding under controlled conditions. International Journal of Ecology Environment Sciences 24: 237-252. 